\title{
Thought Communication, Speed of Movement, and the Spirit's Ability to Absorb Knowledge: Near-Death Experiences and Early Mormon Thought
}

\author{
Brent L. Top, Ph.D. \\ Brigham Young University
}

\begin{abstract}
Three of Charles Flynn's (1986) "core elements" of near-death experiences (NDEs) have special interest to members of the Church of Jesus Christ of Latter-day Saints (Mormons) because of their striking similarity to the doctrinal teachings of 19th-century Mormon leaders and theologians. This article illustrates these three NDE characteristics-thought communication, speed of movement, and the ability to "absorb" knowledge-by comparing contemporary NDE accounts with both the religious teachings of 19th-century Mormon church leaders and the accepted doctrines of modern Mormonism.
\end{abstract}

Virtually all of the recent studies of near-death experiences (NDEs) have included accounts of those who have "died" discovering enhanced abilities, far beyond earthly abilities, in the areas of communication, travel and movement, and the acquisition of knowledge. These three different aspects of the near-death experience, included in Charles Flynn's (1986) list of "core elements" of the NDE, have special interest to Mormons. There are striking similarities between the modern descriptions by NDErs concerning thought communication, the speed of their movements, and their ability to absorb knowledge, and the theological teachings of early Mormon leaders in the

Brent L. Top, Ph.D., is Associate Professor of Church History and Doctrine at Brigham Young University. Reprint requests should be addressed to Dr. Top at the Department of Church History and Doctrine, 316-E Joseph Smith Building, Brigham Young University, P. O. Box 25642, Provo, UT 84602. 
mid-19th century. While there are some accounts of near-death experiences recorded in Mormon literature from both the 19th and 20th centuries, there is no historical evidence that these leaders, whom Mormons accept as modern-day prophets, ever had their own neardeath experiences or were basing their teachings on the experiences of others. They merely taught these concepts as theological facts based on their understanding of scripture and what they purported to be revelations from God.

The purpose of this article is not to prove or disprove the truthfulness of Mormon theology, but merely to show the remarkable parallels between 19th-century Mormon teachings and near-death experiences. Recognizing these similarities and understanding basic Mormon religious beliefs about the afterlife also helps to explain why Mormons exhibit such a strong interest in the field of near-death studies.

\section{Spirit Communication}

In 1829 Joseph Smith, the founder of Mormonism, taught that divine communication consists not of hearing with ears, but rather through thoughts of the mind and feelings of the heart (Doctrine and Covenants, 1981, 8:2). Shortly before his death in 1844, Smith also taught his followers that those who have died "know and understand our thoughts, feelings, and motions" (Smith, 1957, Vol. 6, pp. 50-52). These earliest intimations on spiritual communication were later elaborated with much greater detail by some of the leading Mormon theologians and Church leaders of the day. In a major discourse delivered in the Tabernacle in Salt Lake City on October 22, 1854, Elder Orson Pratt, one of the Church's Twelve Apostles, spoke of "language, or the medium of communication in the future state." In this address, Pratt articulated in great detail the manner of communication that exists among spirit beings after death. He contended that, as the holy scriptures teach, God perceives the thoughts and intents of the heart by a higher power of communication and that communication after death is the utilization of such divine power:

For instance, how does God perceive the thoughts of our hearts? Is there not here a language by which $\mathrm{He}$ can discover and discern the thoughts and intents of the heart? Are we not told in many of the revelations how that God can perceive the thoughts of man, and that for every idle thought we are to be brought into judgment? Yes, 
He discerns the thoughts, and the intents of the hearts of the children of men. Suppose we had some of that power resting upon us, would not that be a different kind of language from sound, or from written language? It would. . . .

For instance, do you suppose that spirits after they leave these bodies, communicate one with another? Do they communicate their ideas by the actual vibrations of the atmosphere the same as we do? I think not. I think if we could be made acquainted with the kind of language by which spirits converse with spirits, we would find that ... they have . . a a more refined system among them of communicating their ideas. This system will be so constructed that they can not only communicate at the same moment upon one subject, as we have to do by making sounds in the atmosphere, but communicate vast numbers of idea, all at the same time, on a great variety of subjects; and the mind will be capable of perceiving them. ... If the mind has such faculty as this, then there must necessarily be a language adapted to such a capacity of the mind. . . .

Well, inquires one, "can you imagine up any such system, or language in this world?" I can imagine up one, but it cannot be made practicable here, from the fact that the mind of man is unable to use it. For instance, the Book of Mormon tells us, that the angels speak by the power of the Holy Ghost, and man when under the influence of it, speaks the language of the angels. Why does he speak in this language? Because the Holy Ghost suggests the ideas which he speaks; and it gives him utterance to convey them to the people. ... Suppose, instead of having arbitrary sounds, such as we have here, to communicate these ideas, that the Holy Ghost itself, through a certain process and power, should enable him to unfold that knowledge to another spirit, all in an instant. (Journal of Discourses, 1855-86, Vol. 3, pp. 100-102)

Such an idea of thought communication among deceased spirits seems to be corroborated by many NDE accounts. It is fascinating that these early Mormon teachings correspond not only with earlier teachings of Swedish philosopher and 18th-century NDEr Emanuel Swedenborg, but also with many accounts recently published in diverse near-death studies. In his classic work Heaven and Hell (1990), Swedenborg described how "angels" communicated with him in his purported visits to the world of spirits:

The angels who sat by my head were silent, only their thoughts communicating with mine. When these thoughts are accepted, the angels know that the person's spirit is in a state to be led out of his body. The communication of their thoughts was accomplished by looking at my face, this being in fact how commuication of thoughts takes place in heaven. (p. 346) 
Swedenborg further asserted that though the spirits of deceased men and women, or what he called "angels," may speak with their lips to mortals, their words are communicated primarily through thought processes:

The speech of angels or spirits with man sounds just as audible as the speech of one person with another. However, it is not audible to people nearby, only to the individual himself. This is because the speech of an angel or spirit flows into the person's thought first, and comes by an inner path to his physical ear; it thus activates it from within. (1990, pp. 178-179)

Numerous near-death experiences illustrate precisely the concept taught by Swedenborg in the 18th century and taught by early Mormon leaders in the early to mid-19th century. Raymond Moody included in Life After Life (1975) the account of an NDEr who reported:

I could see people all around, and I could understand what they were saying. I didn't hear them audibly. . . It was more like knowing what they were thinking, exactly what they were thinking, but only in my mind, not in their actual vocabulary. I would catch it the second before they opened their mouths to speak. (p. 52)

In many other published near-death studies there can be found accounts that reflect this notion of spiritual communication between "mind and heart" that is an integral part of Mormon theology:

I saw people that I knew had died. There were no words spoken, but it was as if I knew what they were thinking and at the same time I knew that they knew what I was thinking. (Grey, 1985, p. 50)

I was seated by the tree of life . . . there I saw many thousand spirits clothed in white. . . . They did not converse by sound, but each knew the other's thoughts at that instant, and conversation was carried on in that way, also with me. (Rogo, 1989, p. 62)

While it is evident from these accounts that afterlife communication is on at least a different, if not higher, plane, it is also clear that the spirit beings of deceased people continue to communicate one with another in much the same sense as women and men in life converse. Through his alleged encounters with "angels" or spirits of deceased people, Swedenborg attested to the notion of continued communication between these deceased spirits on all varieties of subjects:

Angels talk with each other just the way people in the world do, and they talk of various things-household matters, political matters, issues of moral life and issues of spiritual life, for example. 
There is no noticeable difference, except that they talk with each other more intelligently than men do, since they talk more profoundly, from thought. (1990, p. 170)

While many modern NDErs have reported some level of surprise not only at their continued existence but also at the existence and manner of communication between spirits, such ideas are established doctrines of Mormonism. Early doctrinal declarations by Smith, the founder of Mormonism, and by his successor Brigham Young reflected Swedenborg's earlier views and substantiate many modern NDE accounts. "And the same sociality which exists among us here will exist among us there [in the afterlife]," Smith taught his followers in 1843, "only it will be coupled with eternal glory, which glory we do not now enjoy" (Doctrine and Covenants, 1981, 130:2). Six years later Young further elaborated on this concept when he declared: "Spirits will be familiar with spirits in the spirit world, and will converse, behold, and exercise every variety of communication with one another as familiarly and naturally as while here in tabernacles" (1977, p. 380).

\section{Movement and Travel of Spirits After Death}

One of the core elements of the near-death experience described in the works of Kenneth Ring, Flynn, and others is that of the remarkable speed with which the spirit after death can travel. From many NDErs' descriptions of spirit travel, Moody summarized:

Travel, once one gets the hang of it, is apparently exceptionally easy in this state. Physical objects present no barrier, and movement from one place to another can be extremely rapid, almost instantaneous. (1975, p. 46)

This "almost instantaneous" movement of spirit bodies after death may sound like something out of the pages of science fiction, but it is a common element of reported near-death experiences. One example is the Viet Nam veteran whose body was lying wounded on an operating table in a medevac unit, yet he reported that he actually returned to the battlefield where he had been wounded. When he could not get the attention of his comrades who were gathing up the dead bodies, he suddenly found himself back in the operating room. He described the swiftness of his transition by saying: "It was almost like you materialize there and all of a sudden the next instant you 
were over here. It was just like you blinked your eyes" (Sabom, 1982, p. 33).

In an age before there was knowledge of supersonic jet airplanes, fiber optics, and the theory of relativity, Mormon leaders spoke in a similar fashion concerning the remarkable manner in which beings in the spirit realm move and travel from place to place. "As quickly as the spirit is unlocked from this house of clay," Young declared, "it is free to travel with lightning speed to any planet, or fixed star, or to the uttermost part of the earth, or the depths of the sea, according to the will of Him who dictates" (Journal of Discourses, 1855-86, Vol. 13, p. 77). On another occasion, he not only reiterated that spirits can travel at the "speed of lightning" in the next life, but also alluded to the possiblity of some degree of time travel:

[Spirits] move with ease and like lightning. If we want to visit Jerusalem, or this, or that other place-and I presume we will be permitted if we desire-there we are, looking at its streets. If we want to behold Jerusalem as it was in the days of the Saviour; or if we want to see the Garden of Eden as it was created, there we are, and we will see it as it existed spiritually, for it was created first spiritually and then temporally, and spiritually it still remains. And when there we may behold the earth as at the dawn of creation, or we may visit any city we please that exists upon its surface. If we wish to understand how they are living here on these western islands, or in China, we are there; in fact, we are like the light of morning, or, I will not say the electric fluid, but its operations on the wires. God has revealed some little things with regard to His movements and power, and the operation and motion of the lightning furnish a fine illustration of the ability and power of the Almighty. If you could stretch a wire from this room around the world until the two ends nearly met here again and were to apply a battery to one end, if the electrical conditions were perfect, the effect of the touch would pass with such inconceivable velocity that it would be felt at the other end of the wire at the same moment. .

When we pass into the spirit world we shall possess a measure of this power. (Journal of Discourses, 1855-86, Vol. 14, p. 231)

Young's views on spirit travel, expressed in the 19th century, seem to also be reflected in the near-death experience of George Ritchie, who wrote of both speed of travel and the relativity of time that he observed in his travels during his out-of-body experience. He reported that he traveled great distances across the United States at remarkable speeds:

I had made two other discoveries about this strange out-of-body realm. First, one goes wherever his/her soul's sincere desire leads 
him/her. Secondly, time in this realm, if it exists at all, is much shorter that our normal human realm, or the capacity to cover great distances in a regular period of time is vastly increased, for the distance I knew that I had traveled could not be covered in our fastest airplanes. (1991, p. 14)

In addition to Ritchie, others have also given detailed descriptions of their amazing supernatural abilities of movement while out of body. All of the descriptions seem to share many of the same characteristics or ideas that had been advanced by Young and others. One such account, recorded by Michael Sabom, came from a cardiac arrest victim who described his elation upon discovering this new found freedom of movement:

I could have moved away from my body anytime I wanted to. . . . There wasn't a thing that was mechanical about it, like an automobile or anything. It was just a thought process. I felt like I could have thought myself anywhere I wanted to be instantly. . . . I just felt exhilarated with a sense of power. I could do what I wanted to. . . . It's realer than here, really. (Sabom, 1982, p. 34)

One of the central features of virtually all near-death experiences is that of the presence of light-either general emanating light or specific beings of light. It appears that speed or motion as a characteristic of light has something to do with the mode of travel in the next life. Early Mormon theologians, without the benefit of modern knowledge regarding the speed of light, wrote about the role of light in the realm of spirit travel. Parley P. Pratt, an early associate of Mormon founder Smith and an Apostle in the Church during Young's administration, taught that the nature of the spirit body is a factor in its proficiency in supernatural movement:

It is true that this subtle fluid or spiritual element is endowed with powers of locomotion in a far greater degree than the more gross or solid elements of nature; that its refined particles penetrate amid the other elements with greater ease, and meet with less resistance from the air or other substances, than would the more gross elements. Hence, its speed, or superior powers of motion. (Journal of Discourses, 1855-86, Vol. 1, p. 8)

Pratt's brother, Orson Pratt, also a 19th century Apostle in the Church of Jesus Christ of Latter-day Saints and considered one of the greatest Mormon theologians, in a monumental discourse on conditions of the next life, implied that because the spirit bodies of the deceased are composed of light they are able to travel at the speed of light: 
What does the Lord say in one of the new revelations? "Ye shall live by every word that cometh out of the mouth of God; whatsoever is truth is light and whatsoever is light is spirit," consequently the light that comes from the sun is spirit. How fast does that spirit travel? It can be demonstrated that it can travel [at the speed of light]; if then one portion of spirit can travel with that velocity, it is natural for us to suppose that any other portions of spirit can travel with the same velocity, and thus we shall be able to accomplish, and perform a greater amount of righteousness among other worlds and beings, than if we were compelled to lose three fourths, or nine tenths of our time on the journey. (Journal of Discourses, 1855-86, Vol. 3, p. 104)

\section{Ability to Absorb Knowledge}

Many NDErs report that one of the most significant aspects of their unique experience, alongside an overwhelming sense of love, is a profound encounter with knowledge. Moody (1977) characterized this increased intellectual and spiritual ability as a "vision of knowledge." Noting that NDErs state that a complete expression of this experience is impossible in this life, he observed that they

got brief glimpses of an entire separate realm of existence in which all knowledge-whether of past, present, or future-seemed to coexist in a sort of timeless state. Alternately, this has been described as a moment of enlightenment in which the subject seemed to have complete knowledge. (pp. 9-10)

Moody then provided several specific examples of this phenomenon. One woman explained:

It seemed that all of a sudden, all knowledge - of all that had started from the very beginning, that would go on without end-that for a second I knew all the secrets of all ages, all the meaning of the universe, the stars, the moon-of everything. (p. 10)

When questioned by Moody as to how this knowledge was presented to her, she replied:

It was in all forms of communication, sights, sounds, thoughts. It was any- and everything. It was as if there was nothing that wasn't known. All knowledge was there, not just of one field, but everything. (p. 11)

Another person Moody interviewed put it this way: 
Because this is a place where the place is knowledge. . . Knowledge and information are readily available-all knowledge. ... You absorb knowledge. ... Y You all of a sudden know the answers. (p. 14)

Ring has also reported numerous accounts from his near-death research that demonstrate a "heightened sensory awareness" in which experiencers feel more alive, vibrant, and aware intellectually than when in their bodies. A man who was the victim of an attempted murder reported:

As my senses expanded I became aware of colors that were far beyond the spectrum of the rainbow known to the human eye. My awareness stretched out in all three hundred sixty degrees. (Ring, 1984, p. 65)

Another NDEr in Ring's research described similar feelings: "It was as if my whole body had eyes and ears. I was just so aware of everything" (Ring, 1980, p. 93). Many other accounts seem to confirm this rarified sense of awareness and the unique ability to absorb knowledge through senses beyond those earthly. This intriguing aspect of NDEs also seems to coincide closely with the views expressed centuries ago by Swedenborg:

For the human mind is just as discerning as the angelic mind. The reason it is not so discerning in the world is that it is within an earthly body, within which a spiritual mind thinks in a natural fashion. But it is quite different when it is released from its tie with the body. Then it no longer thinks in a natural way, but in a spiritual way; and when it does, it thinks about matters unintelligible and inexpressible to the natural person-so it discerns like an angel. (1990, p. 237)

People who are in heaven have far more delicate senses (that is, they see and hear far more precisely) and they think more wisely that when they were in the world. For they see by heaven's light, which surpasses earth's light by many degrees; they hear, too, through a spiritual atmosphere, which also surpasses the earthly one by many degrees. $(1990$, p. 359$)$

Swedenborg's teachings and NDErs' descriptions of their ability to absorb knowledge strike a familiar chord to Mormons. Such views were reflected not only in the teachings of Mormon leaders in the 19th century, but are also evident in sacred writings esteemed by Mormons as scripture. One such scriptural account dealt with how Moses was somehow spiritually empowered to view the existence of the world from beginning to end, comprehending every particle of it 
and every being who would ever occupy it. Moses' own account of this experience provides some detail:

And it came to pass, as the voice [of God] was still speaking, Moses cast his eyes and beheld the earth, yea, even all of it; and there was not a particle of it which he did not behold, discerning it by the spirit of God. And he beheld also the inhabitants thereof, and there was not a soul which he beheld not; and he discerned them by the spirit of God, and their numbers were great, even numberless as the sand upon the sea shore. (The Pearl of Great Price, 1981, Moses 1:27-28 [italics added])

There are other accounts in Mormon holy writ that demonstrate this remarkable ability to absorb and comprehend knowledge in a supernatural way- "by the spirit of God"-that seems to coincide to some degree with the descriptions given by NDErs. Additionally, there are several fascinating discourses given on the subject by Mormon leaders and theologians in the last century. One of the most significant, "The Increased Powers and Faculties of the Mind in the Future State," was given in 1854 by Elder Orson Pratt of the Church's Quorum of the Twelve Apostles. It is interesting to note the similarities of his doctrinal teachings to the actual descriptions of near-death experiences today:

When the Lord imparts to us a principle [the spirit of God] by which we can look upon the past and future, as well as the present-by which we can look upon many intricate objects of nature which are now hidden from our view-we shall find our capacity for obtaining and retaining knowledge to be greatly enlarged. (Journal of Discourses, 1855-86, Vol. 2, p. 247)

In that oration, he further elaborated on these magnified sensory abilities of spirits, in a manner similar to Swedenborg's descriptions of "angelic discernment":

Here, then, is a new faculty of knowledge, very extended in its nature, that is calculated to throw a vast amount of information upon the mind of man, almost in the twinkling of an eye. How long a time would it take a man in the next world, if he had to gain knowledge as we do here, to find out the simplest things in nature? $\mathrm{He}$ might reason, and reason for thousands of years, and then hardly have got started. But when this Spirit of God, this great telescope that is used in the celestial heavens, is given to man, and he, through the aid of it, gazes upon eternal things, what does he behold? Not one object at a time, but a vast multitude of objects rush before his vision, and are present before his mind, filling him in a moment with the knowledge of worlds more numerous than the sands of the sea shore? Will he be able to bear it? Yes, his mind is 
strengthened in proportion to the amount of information imparted. It is this tabernacle, in its present condition, that prevents us from a more enlarged understanding.

There is a faculty mentioned in the word of God, which we are not in possession of here, but we shall possess it hereafter; that is not only to see a vast number of things in the same moment, looking in all directions by the aid of the Spirit, but also to obtain a vast number of ideas at the same instant. . . .

I believe we shall be freed in the next world, in a great measure, from these narrow, contracted methods of thinking. Instead of thinking in one channel, and following up one certain course of reasoning to find a certain truth, knowledge will rush in from all quarters; it will come in like the light which flows from the sun, penetrating every part, informing the spirit, and giving understanding concerning ten thousand things at the same time; and the mind will be capable of receiving and retaining all. (Journal of Discourses, 185586, Vol. 2, p. 246)

Just as Swedenborg taught the physical body was the main impediment in gaining and comprehending this type of knowledge, Pratt also taught that it is when we leave the physical world and our physical body behind that our intellect will become most enlivened. He taught that we not only will be able to learn more, but will also be able to regain that which we have learned before but have lost as mortal memories dim:

Some of the knowledge we receive here at one time becomes so completely obliterated, through the weakness of the animal system, that we cannot call it to mind, no association of ideas will again suggest it to our minds; it is gone, erased, eradicated from the tablet of our memories. This is not owing to the want of the capacity of the spirit; no, but the spirit has full capacity to remember. . . . It is not the want of capacity in the spirit of man that causes him to forget the knowledge he may have learned yesterday; but it is because of the imperfection of the tabernacle in which the spirit dwells; because there is imperfection in the organization of the flesh and bones, and in things pertaining to the tabernacle; it is this that erases from our memory many things that would be useful; we cannot retain them in our minds, they are gone into oblivion. It is not so with the spirit when it is released from this tabernacle. . . . Wait until these mortal bodies are laid in the tomb; when we return home to God who gave us life; then is the time we shall have the most vivid knowledge of all the past acts of our lives during our probationary state. (Journal of Discourses, Vol. 2, p. 239)

This supernatural intellectual ability, which includes what could be characterized as "perfect spirit memory," is no doubt related to the life review that is an integral element of near-death experiences 
and correlates with Swedenborg's view that in the next life "the most minute details of everything can be drawn from someone's memory, even things he himself has forgotten in the world" (1990, p. 364). Several references to this "perfect spirit memory" can also be found in Mormonism's foundational volume of scripture known as The Book of Mormon (1981). There are several passages in The Book of Mormon that testify of a supernatural memory of one's life that comes to one at death. "Now there is a death which is called the temporal death;" the prophet Amulek wrote, " . . . and we shall be brought to stand before God, knowing even as we know now, and have a bright recollection of all our guilt" (Book of Mormon, Alma, 11:42-43). Other Book of Mormon prophets also spoke of this "bright recollection." Jacob, one of the first prophets in the book, spoke of a "perfect knowledge" that comes to each person after death and will play an important role in the final judgment of each individual:

... and the spirit and the body is restored to itself again, and all men become incorruptible, and immortal, and they are living souls, having a perfect knowledge like unto us in the flesh, save it be that our knowledge shall be perfect.

Wherefore, we shall have a perfect knowledge of all our guilt, and our uncleanness, and our nakedness; and the righteous shall have a perfect knowledge of their enjoyment, and their righteousness, being clothed with purity, yea, even with the robe of righteousness.

And it shall come to pass that when all men shall have passed from this first death unto life, insomuch as they have become immortal, they must appear before the judgment seat of the Holy One of Israel; and then cometh the judgment, and then they must be judged according to the holy judgment of God. (Book of Mormon, 2 Nephi 9:13-15; see also Mosiah 3:25; Alma 5:18; and Alma 12:14-15)

It is clear from Mormon teachings-both from their scriptures and from sermons of early leaders-that this "perfect knowledge" serves a spiritual purpose in self-examination and in the ultimate judgment of humankind. Herein lies the relationship between what Mormons would characterize as "perfect spirit memory" or "perfect knowledge" and what many NDErs describe in the accounts of their "life review." The following account seems to characterize NDErs' descriptions and reflects the theological teachings found in Mormon thought as well as the postulates of Swedenborg:

It was like I knew everything that was stored in my brain. Everything I'd ever known from the beginning of my life I knew about. And also what was kind of scary was that I knew everybody else in the room knew and there was no hiding anything-the good 
times, the bad times, everything. . . . I had total complete clear knoweldge of everything that had ever happened in my life-even the little things that I had forgotten. . . Everything was so clear. (Ring, 1984, pp. 68-69)

Most NDErs report that, next only to the overwhelming feeling of love, knowledge is the most profound aspect of their experience. Their descriptions of the spirit realm being a place of knowledge and learning and of their own unique abilities to absorb knowledge and remember things are familiar themes in Mormonism. One of the most familiar scriptural passages to Mormons- "The glory of God is intelligence" (Doctrine and Covenants, 1981, 93:36)-helps explain why such near-death accounts of knowledge and learning abilities are interesting to Mormons, as the concepts contained in such descriptions are fundamental Mormon beliefs.

\section{Conclusion}

Many of the "core elements" of near-death experiences that have been recounted and published in the last half of the 20th century find a familiar "home" among Mormons because of the similar concepts found in Mormon scripture and sermons of early leaders. In the three areas discussed in this paper-communication, movement and travel, and the absorption of knowledge-there are striking similarities between the descriptions of NDErs of today and the writings and teachings within 19th century Mormonism. While there is no historical evidence that these early Mormon leaders had personal near-death experiences, their sermons certainly contain much of the same descriptions and information that modern near-death accounts do.

When coupled with the numerous descriptions, teachings, and accounts in other religious and cultural traditions, we can see that the messages received and the lessons learned about the immortality of the soul and the remarkable conditions of the afterlife transcend culture, religion, and science. This indicates that near-death experiences have a significant religious meaning that can and should be studied theologically as well as medically, socially, culturally, or psychologically. While many Christian denominations seem uncomfortable with near-death research, the teachings of Mormonism share much common ground with NDEs. Although near-death experiences did not play any actual signficant role in Mormonism's theological develop- 
ment, it is interesting to note the many parallels can be found between NDEs and the religious teachings of Mormonism.

\section{References}

Book of Mormon, The. (1981). Salt Lake City, UT: Church of Jesus Christ of Latter-day Saints.

Doctrine and Covenants, The. (1981). Salt Lake City, UT. Church of Jesus Christ of Latter-day Saints.

Flynn, C. P. (1986). After the beyond: Human transformation and the near-death experience. Englewood Cliffs, NJ: Prentice-Hall.

Grey, M. (1985). Return from death: An exploration of the near-death experience. London, England: Arkana.

Journal of Discourses. (1855-86). Liverpool, England: F. D. Richards and Sons.

Moody, R. A. (1975). Life after life. Covington, GA: Mockingbird Books.

Moody, R. A. (1977). Reflections on life after life. St. Simon's Island, GA: Mockingbird Books.

Pearl of Great Price, The. (1981). Salt Lake City, UT. Church of Jesus Christ of Latter-day Saints.

Ring, $\mathrm{K}$ (1980). Life at death: $A$ scientific investigation of the near-death experience. New York, NY: Coward, McCann and Geoghegan.

Ring, K (1984). Heading toward omega: In search of the meaning of the near-death experience. New York, NY: Morrow.

Ritchie, G. (1991). My life after dying. Norfolk, VA: Hampton Roads.

Rogo, D. S. (1989). The return from silence: A study of near-death experiences. Wellingborough, England: Aquarian Press.

Sabom, M. B. (1982). Recollections of death: A medical investigation. New York, NY: Harper and Row.

Smith, J. (1957). History of the Church of Jesus Christ of Latter-day Saints (2nd ed, rev.) (Ed. by B. H. Roberts). Salt Lake City, UT. Deseret.

Swedenborg, E. (1990). Heaven and hell (Trans. by G. F. Dole). New York, NY: Swedenborg Foundation.

Young, B. (1977). Discourses of Brigham Young (Ed. by J. A. Widtsoe). Salt Lake City, UT. Deseret. 